\title{
First record of Glossophaga soricina (Pallas, 1766) (Chiroptera, Phyllostomidae) in the province of Corrientes, Argentina
}

\author{
Miranda J. Collett ${ }^{1}$, Melisa D’Occhio \\ 1 Collett Trust for Endangered Species, Reserva Don Luis, Esteros del Iberá, Ituzaingó, 3302 Corrientes, Argentina. 2 Universidad Nacional de \\ Avellaneda, Departamento de Ambiente y Turismo, España 350, Avellaneda, 1870 Buenos Aires, Argentina. \\ Corresponding author: Miranda J. Collett, miranda@collett-trust.org
}

\begin{abstract}
Pallas's Long-tongued Bat, Glossophaga soricina (Pallas, 1766), has a large range, covering much of the Neotropics. Until this study, Argentine records for this species were restricted to Misiones, Chaco, Salta, Jujuy and unverifiable records from Buenos Aires. We report the discovery of this nectarivorous bat in Corrientes, extending its known range and increasing the number of bat species recorded in this province to 32. An adult male was captured in Apipé Grande island in October 2019. This bat species is considered Vulnerable in Argentina and needs urgent conservation action in order to avoid further threats.
\end{abstract}

\section{Keywords}

Distribution, nectarivorous bat, Neotropics.

Citation: Collett MJ, D’Occhio M (2020) First record of Glossophaga soricina (Pallas, 1766) (Chiroptera, Phyllostomidae) in the province of Corrientes, Argentina. Check List 16 (5): 1115-1118. https://doi.org/10.15560/16.5.1115

\section{Introduction}

Corrientes province is situated in the northeast of Argentina, surrounded by two of the most important rivers in southern South America, the Paraná and Uruguay. The Iberá wetlands (Esteros del Iberá), renowned for their rich biodiversity, are situated in the heart of Corrientes province, constituting the second largest wetlands in the Americas. During the past 25 years, Corrientes has been subject to massive expansion of its industrial conifer and Eucalyptus L'Hér. plantations, in part due to economic incentives from the government (Peri et al. 2015). The Provincial government has set a target of one million hectares to be planted by 2025 , which is around $12 \%$ of the area of the entire province (Busscher et al. 2019). This often involves native deforestation, which causes depletion in resources used by bats leading to a decrease in their functional richness as deforestation increases (Garcia-Morales et al. 2016). On top of that, the bulk of the province has little information regarding bat diversity, including Apipé Grande island, where few bat surveys have been undertaken. Parts of the island have experienced deforestation, with native forests being replaced with plantations of pines and Eucalyptus spp. Situated in the north of the province of Corrientes, this island consists of approximately 27,500 ha, 6,000 of which were declared as a Provincial Natural Reserve in 1994 (Fontana 2008).

Thirty-one species of bats, belonging to four families (Noctilionidae, Phyllostomidae, Vespertilionidae and 
Molossidae), have been recorded in the province (Argoitia et al. 2019). Members of the subfamily Glossophaginae (family Phyllostomidae) are predominantly nectarivorous and are usually small-bodied with a long muzzle and tongue adapted for feeding on nectar (Barquez et al. 1999). The genus Glossophaga E.Geoffroy, 1818 includes five species, all found in the Neotropics. Glossophaga soricina (Pallas, 1766) is the most abundant of the genus and has the largest range, from northern Mexico to northern Argentina. It also occurs in Trinidad, Isla Margarita, Jamaica and Tres Marias islands (Alvarez et al. 1991). This species plays an important role in the pollination of plants that flower at night, including many cactus species (Fleming et al. 2009).

Glossophaga soricina is the only member of its genus in Argentina, representing, along with Anoura caudifer (É. Geoffroy, 1818), one of the two nectarivorous bats in the country. Although predominantly consuming nectar and pollen, G. soricina is also considered omnivorous, complementing its diet with fruit and insects (Clare et al. 2013). Previous records of this species in Argentina come from various ecoregions, including the Yungas of Salta and Jujuy, the Chaqueña of Chaco and the Selva Paranaense of Misiones (Boero et al. 2019). Here we report its occurrence in Corrientes, extending its known range and increasing the number of bat species recorded in this province.

\section{Methods}

Bats were studied in San Antonio, capital of Apipé island, which is located in the River Paraná, between Argentina and Paraguay (Fig. 1). The vegetation of this island is characteristic of the Paranaense ecoregion (Cabrera 1976), and the climate is subtropical (Fontana 2008). La Casona is a small sustainable ecolodge, which is surrounded by mature native trees and provides roosts for several bat species. We used a variety of mist nets placed in open spaces and close to fruiting trees to increase the probability of captures and to ensure a better representation of the local bat diversity. Nets were ultrafine (Ecotone, Poland), designed specifically for catching small bats, and we used three sizes: a triple high net $(12 \times 7.2$ $\mathrm{m})$, a double high net $(9 \times 4.8 \mathrm{~m})$ and a single net $(12 \times$ $2.4 \mathrm{~m})$. They were opened after sunset at 19:20 local time on 15 October 2019, and the session lasted for four hours. Nets were checked every 15 minutes to minimize distress on captured bats. Individuals were weighed, measured and photographed and then released after minimal handling.

The protocol for handling bats followed the advice of Mitchell-Jones and McLeish (2004), and permission for the research was given by the local authorities (Dirección de Parques y Reservas de Corrientes and Dirección de Recursos Naturales de Corrientes). Individuals captured were identified by comparing external morphological



Figure 1. Distribution map of Glossophaga soricina in Argentina. The inset is an enlargement of the Isla Apipé Grande, situated in the River Parana between Argentina and Paraguay, in which we captured the bat. 
features with descriptions authored by Barquez et al. (1999), Gardner (2008), Barquez and Diaz (2009), and Diaz et al. (2016).

\section{Results}

\section{Glossophaga soricina (Pallas, 1766)}

Figures 1, 2

New record. ARGENTINA $\bullet 1$ adult $\widehat{\jmath}$, weight $11 \mathrm{~g}$, forearm $35.4 \mathrm{~mm}$; Corrientes province, Ituzaingó department, Apipé Grande island, San Antonio, Ecolodge La Casona; $27.5075^{\circ} \mathrm{S}, 056.7444^{\circ} \mathrm{W}$; alt. ca $70 \mathrm{~m} ; 15$ Oct. 2019; M.J. Collett leg; mist net $12 \times 4.8 \mathrm{~m}$; individual measured, photographed and released. (Data uploaded to GBIF: https://doi.org/10.15468/kntyh2; Collett 2020).

As well as $G$. soricina, 12 other bats from five species were captured during the same netting session, including: Platyrrhinus lineatus (É. Geoffroy, 1810), Eptesicus furinalis (d'Orbigny \& Gervais, 1847), Lasiurus blossevillii (Lesson \& Garnot, 1826), Myotis nigricans (Schinz, 1821), and Eumops patagonicus Thomas, 1924.

Identification. The diagnostic characteristics of $G$. soricina, all recorded in the individual from Corrientes, are as follows: elongated muzzle, small noseleaf, long tongue, presence of lower incisors, and a well-developed uropatagium. The only other genus of Glossophaginae recorded in Argentina is Anoura Gray, 1838, which is diagnosed, among other characteristics, by a reduced uropatagium and absence of lower incisors. In South America, there are two other species of Glossophaga that are similar to G. soricina: G. commissarisi Gardner, 1962 and G. longirostris Miller, 1898. Glossophaga commissarisi has upper incisors that are not noticeably procumbent and lower incisors with spaces between them (Webster and Knox Jones Jr. 1993). While both $G$. soricina and $G$. longirostris have procumbent upper incisors and crowded lower incisors, the latter has upper incisors that are equally procumbent (Webster et al. 1998) whereas in our individual the tip of I1 protruded well beyond the tip of I2.

\section{Discussion}

The discovery of Glossophaga soricina in Corrientes expands the known range of this rare species in Argentina to five provinces in the north of the country, although the records are sparse. In addition, there are some old records of this species from the province of Buenos Aires, where winter frosts are prevalent, but there is uncertainty about their validity. It probably had a more southerly distribution early in the 20th century, when the gallery forests extended further south. This habitat has largely disappeared, and the present range of the species is unknown (Barquez et al. 1999).

Our discovery closes the gap between records of this species in Chaco and those in Misiones provinces, giving it a wide distribution in the north of Argentina (Fig. 1). The nearest documented record of G. soricina from our new locality, is to the northeast, in San Ignacio, Misiones, close to the River Parana. The distance

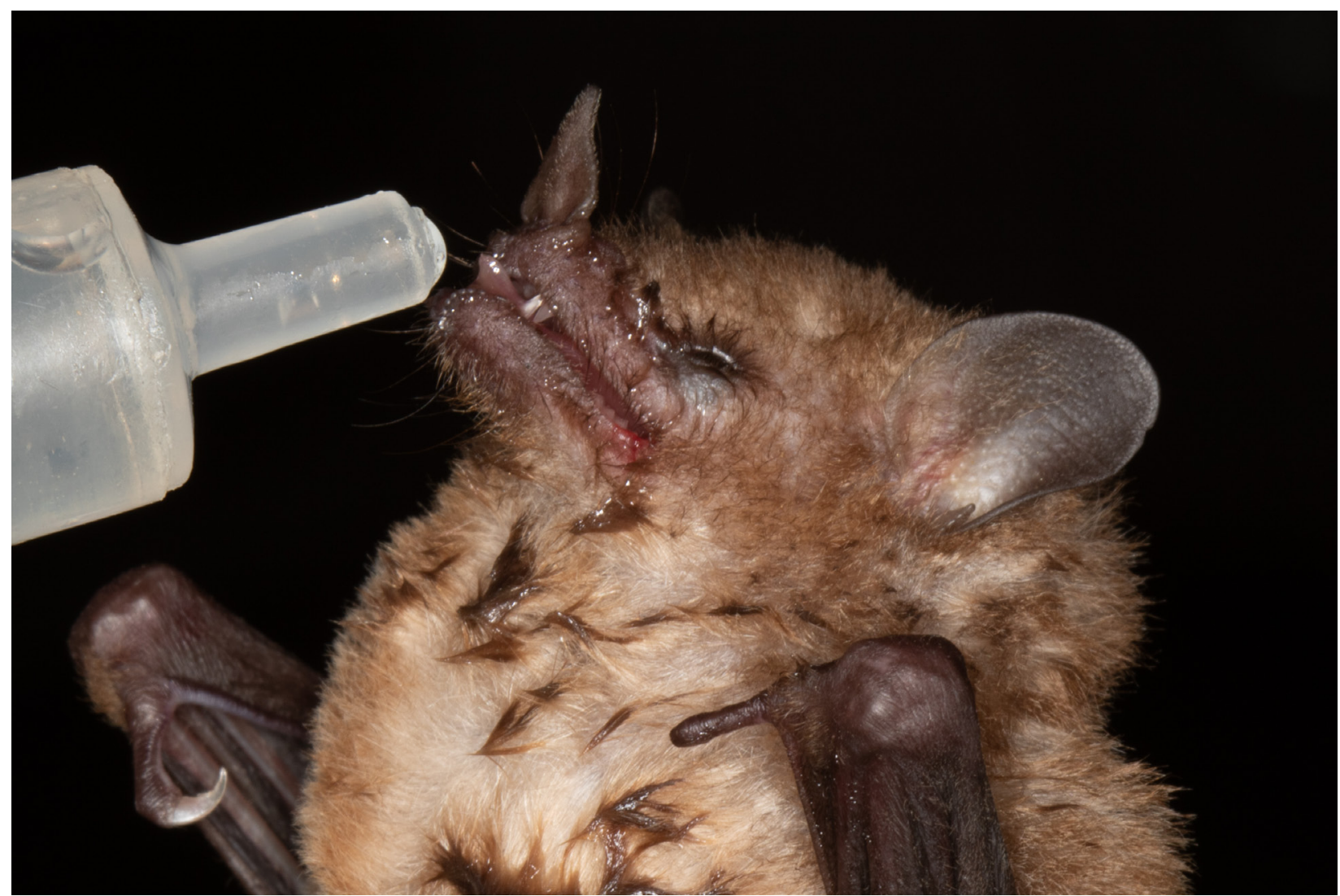

Figure 2. Adult male of Glossophaga soricina, from La Casona, Isla Apipé Grande, Corrientes, Argentina, being fed with a sugar solution. 
between this site and the capture site in Apipé Grande is $118 \mathrm{~km}$. Glossophaga soricina is found in Bolivia, Paraguay and Brazil, all countries that border the north of Argentina. It was expected, therefore, that this species would also occur in Formosa province.

Glossophaga soricina is considered Least Concern globally (Barquez et al. 2015), but in Argentina it is considered Vulnerable (Boero et al. 2019). It is estimated to have suffered a $30 \%$ decline in the last 17 years, mainly due to the loss and degradation of its habitats caused by anthropogenic activities. This species is rare in Argentina and needs protection against further deforestation and fragmentation of its habitat, in particular of the gallery forests that are associated with the River Paraná. More research on its diet and habitat preferences will also be important for the establishment of management actions favoring its survival in Corrientes and in other provinces of northern Argentina.

\section{Acknowledgements}

We thank the authorities from Corrientes (Dirección de Parques y Reservas, and Dirección de Recursos Naturales) for their approval to conduct our bat research; Aníbal de la Cruz and Silvia Batista for their hospitality at the Ecolodge La Casona and for allowing us to place our nets on their property; and Alejandra Boloqui, Cepi Oporto and Leo Georgadis for assisting with the research, which was funded by the Collett Trust for Endangered Species. Finally, we acknowledge the reviewers of the manuscript.

\section{Authors' Contributions}

MJC and MD participated in the specimen capture, MJC reviewed and identified the species, MJC and MD wrote the text.

\section{References}

Alvarez J, Willig M, Knox Jones J, Webster W (1991) Glossophaga soricina. Mammalian Species 379: 1-7. https://doi.org/10. 2307/3504146

Argoitia A, Cajade R, Pineiro J, Teta P (2019) Nuevas localidades y notas sobre la historia natural de los murciélagos (Chiroptera: Phyllostomidae, Vespertilionidae y Molossidae) de la provincia de Corrientes, Argentina. Notas sobre mamíferos Sudamericanos 12: 1-11. https://doi.org/10.31687/saremNMS.19.0.12

Barquez, RM, Díaz MM (2009) Los murciélagos de Argentina. Clave de identificación. Publicación especial No 1 PCMA (Programa de Conservación de Murciélagos de Argentina). Editorial Magna Publicaciones, Tucumán, 80 pp.
Barquez RM, Mares MA, Braun JK (1999) The bats of Argentina. Special publications, Museum of Texas Tech University 42: 1-275.

Barquez R, Perez S, Miller B, Díaz M(2015) Glossophaga soricina. The IUCN Redlist of Threatened Species: 2015: e.T9277A22107768. https://doi.org/10.2305/iucn.uk.2015-4.rlts.t9277a22107768. en. Accessed on: 2020-6-28.

Boero L, Palmerio A, Díaz M, Barquez R (2019) Glossophaga soricina. In: SAyDS-SAREM (Eds) Categorización 2019 de los mamíferos de Argentina según su riesgo de extinción. Lista Roja de los mamíferos de Argentina. http://cma.sarem.org.ar. Accessed on: 2020-06-28.

Busscher N, Parra C, Vanclay F (2019) Environmental justice implications of land grabbing for industrial agriculture and forestry in Argentina. Journal of Environmental Planning and Management 63 (3): 500-522. https://doi.org/101080/09640568.2019.1595546

Cabrera AL (1976) Regiones fitogeográficas argentinas. ACME, Buenos Aires, $85 \mathrm{pp}$.

Clare EL, Goerlitz HR, Drapeau VA, Holderied MW, Adams AM, Nagel J, Dumond ER, Hebert PDN, Brock Fenton M (2013) Trophic niche flexibility in Glossophaga soricina: how a nectar seeker sneaks an insect snack. British Ecological Society, Funcional Ecology 28 (3): 632-641.

Collett M (2020). first_glossophaginae_corrientes_argentina. Check List. Metadata dataset. https://doi.org/10.15468/kntyh2. Accessed via GBIF.org on 2020-9-2.

Díaz MM, Solari S, Aguirre LF, Aguiar LM, Barquez RM (2016) Clave de identificación de los murciélagos de Sudamerica. Special publication No 2, PCMA (Programa de Conservación de los Murciélagos de Argentina). Magna Publicaciónes, Tucumán, 160 pp.

Fleming TH, Geiselman C, Kress WJ (2009) The evolution of bat pollination. Oxford Academic, Annals of Botany 104 (6): 1017-1043. https://doi.org/10.1093/aob/mcp197

Fontana JL (2008) Vegetación y diversidad de ambientes en la Reserva Natural Isla Apipé Grande, provincia de Corrientes, Argentina. Insugeo, Miscelánea 17 (2): 407-424.

Garcia-Morales R, Moreno CE, Badano EI, Zuria I, Galindo-González J, Rojas-Martinez AE, Ávila-Gómez ES (2016) Deforestation impacts on bat functional diversity in tropical landscapes. PLoS ONE 11 (12): e0166765. https://doi.org/10.1371/journal.pone. 0166765

Gardner AL (2008) Mammals of South America, Volume 1: marsupials, xenarthrans, shrews and bats. University of Chicago Press, Chicago, 690 pp. https://doi.org/10.7208/chicago/9780226282428. 001.0001

Mitchell-Jones AJ, McLeish AP (2004) Bat workers manual, Joint Nature Conservation Committee, 3rd edition. Pelagic Publishing, Exeter, 178 pp.

Peri PL, Paez JA, Marcovecchio J, Carranza C, Laclau P, Schlichter T (2015) Política forestal en apoyo a la implementación de sistemas silvopastoriles en Argentina. 3rd Congreso Nacional de Sistemas Silvopastoriles and VIII Congreso Internacional Sistemas Agroforestales in Iguazú. 7-9 May 2015. Ediciones INTA, Montecarlo, 391-396.

Webster WD, Handley Jr. CO, Soriano PJ (1998) Glossophaga longirostris. Mammalian Species 576: 1-5.

Webster WD, Knox Jones Jr. J (1993) Glossophaga commissarisi. Mammalian Species 446: 1-4. 